\title{
YKSILÖLLISYYDEN POLITIIKKA ELINA HIRVOSEN DOKUMENTTIELOKUVASSA KIEHUMISPISTE
}

Elina Hirvonen tarkastelee dokumenttielokuvassaan Kiehumispiste (2017) suomalaisten ja maahanmuuttajien monimutkaista suhdetta tunteiden ja subjektiivisuuden kautta. Analysoin tässä artikkelissa Kiehumispistettä yhdistämällä Susanna Helken ajattelua suomalaisen dokumenttielokuvan emotiivisesta käänteestä ja Slavoj Žižekin politiikan kulturalisaation teoriaa.

\section{Johdanto}

Tavoitteena ei ole yhteinen näkemys eikä toisen osapuolen mielipiteen tukahduttaminen... Jos kaikki puhuvat ja kuuntelevat, niin kaikkien ymmärrys lisääntyy. (Marten 2017.)

Tarkastelen tässä artikkelissa Elina Hirvosen dokumenttielokuvaa Kiehumispiste (2017), joka käsittelee useita monimutkaisia 2010-luvun suomalaista yhteiskuntaa koskettavia poliittisia ja yhteiskunnallisia kysymyksiä. Kiehumispisteen lähestymistapa heijastaa suomalaisen nykydokumenttielokuvan laajempaa suuntausta, jossa tunteet nousevat tärkeämmäksi kuin poliittinen konteksti, tosiasiat tai analyysi.

Perustelen tulkintani viittaamalla suomalaisen dokumenttielokuvantekijän ja -tutkijan Susanna Helken ja kulttuurifilosofi Slavoj Žižekin ajatteluun. Helken (2016) mukaan on syytä tarkastella huolellisesti, miten poliittisia teemoja käsitellään ja mikä asema niille annetaan nykydokumenttielokuvissa. Tämä on tärkeää siksi, että samalla kun niin sanotun emotiivisen käänteen myötä henkilökohtaiset uskomukset, filosofiat ja elokuvantekijöiden ja heidän kuvauskohteidensa identiteetit ovat nousseet dokumenttielokuvien keskiöön, yksilöiden kehittymiseen vaikuttavat kompleksiset poliittiset rakenteet ovat jääneet vähemmälle huomiolle.

Viittaan myös Slavoj Žižekin politiikan kulturalisaatiota käsittelevään teoriaan (2007). Žižekin mukaan kyseessä on prosessi, jossa yksinkertaistetut kulttuuriset narratiivit korvaavat terävämmät rasismia ja etnistä marginalisaatiota koskevat poliittiset tutkimukset. Näkemykseni mukaan Helken ja 
Žižekin ajattelussa on yhdenmukaisuutta, mikä mahdollistaa sen, että tunteita korostava emotiivinen käänne voidaan nähdä esimerkkinä kulturalisaatiosta.

Kuten yllä siteeratusta elokuvan nettisivulla olleesta toteamuksesta käy ilmi, elokuvan dokumentaarisen eetoksen motiivina ei ole konsensus vaan sen vastakohta, vastakkaisten mielipiteiden dialogi. Tarkastelen tätä lähtökohtaa kriittisesti ja esitän, että Kiehumispisteessä "dialogi" vastaa yksilöllistynyttä subjektiviteettia, joka heijastaa 2010-luvun suomalaisen poliittisen maiseman uusliberalistisia tendenssejä. Aloitan kuitenkin tarkastelemalla suomalaisen dokumenttielokuvan kentällä tapahtuneita muutoksia suhteessa siihen, miten yksilökeskeisyys nousi hallitsevaksi trendiksi.

\section{Meistä minuun: poliittisen dokumentin evoluutio minän aikakaudella}

Helke jakaa suomalaisen dokumenttielokuvan kehityksen karkeasti kolmeen vaiheeseen. Ensimmäisessä vaiheessa toisen maailmansodan molemmin puolin dokumentaarisen elokuvan genre syntyi väyläksi kommunikoida vakavia poliittisia ja sosiaalisia aiheita. Retorisesti dokumentit tukeutuivat kollektiivisen konsensuksen tyyliin, joka suunnattiin oletetulle kollektiiviselle yleisölle. (Helke 2016, 184.) Tämä konsensus oli rinnakkainen hallituksen pyrkimyksille vahvistaa hyvinvointivaltiota kollektiivisen sosiaalisen muutoksen välineenä.

Tämä on erityisen tärkeää Pohjoismaissa, kun ajatellaan hyvinvointivaltion asemaa dokumenttielokuvakulttuurin muotoutumisessa. Hyvinvointimalli on muokannut pohjoismaisten yhteiskuntien sosiaalisia konventioita ja koodistoa lähes seitsemän vuosikymmenen ajan. Historiallisista ja kehityksellisistä eroista huolimatta kaikkia viittä Pohjoismaata yhdistävät yleisellä tasolla samat, yhteiskunnan jatkuvuutta ja kollektiivista vastuuta korostavat periaatteet. Johannes Kananen (2014) määrittelee osuvasti järjestelmän, jota usein kutsutaan "Pohjolan malliksi" (the Nordic Model): se on yhdistelmä kapitalistisia talouskäytänteitä ja sosialistisia arvoja, joita rahoitetaan tulonsiirroin korkeasta verotuksesta saatavilla varoilla.

Niin Suomessa kuin muissa Pohjoismaissa on olennaista tarkastella valtion roolia dokumenttielokuvan muotoutumisessa. Erityisen tärkeää tarkastelu on pohjoismaisen hyvinvointivaltion kollektivistisen luonteen sekä sen kannalta, miten tuo luonne on siirtynyt kohti individualistisempaa mielenlaatua. Dokumentaarisella elokuvalla on Suomessa merkittävä asema niin historian kuin nykyhetken näkökulmasta. Suomalaisten dokumenttielokuvien rahoitusinfrastruktuuri rakentuukin ensi sijassa kansallisten toimijoiden, Yleisradion, Suomen elokuvasäätiön ja Audiovisuaalisen kulttuurin edistämiskeskuksen ympärille. Tämä vankka tukijärjestelmä, joka syntyi 1970-luvulla, oli seurausta television menestyksestä ja sen piirissä tehdystä tietoisesta panostuksesta hiipuvaan suomalaiseen elokuvateollisuuteen. Suomen elokuvasäätiössä erityisesti dokumenttielokuvaa pidettiin kansallisen kulttuurin ilmaisukanavana (Kääpä \& Sills-Jones 2016, 91). Tämä liittyy läheisesti Helken ajatukseen suomalaisen dokumenttielokuvan kollektivistisen konsensuksen tyylistä.

Helken $(2016,187)$ mukaan dokumenttielokuvan historiallisen kehityksen lähtökohta on siis kollektiivisuuden ajatus. Hän väittää, että siitä siirryttiin 1980-luvulla kohti taiteellisempia ja omaelämäkerrallisempia suuntia, kun elokuvantekijät ja taiteilijat alkoivat käsitellä poliittisia teemoja henkilökohtaisemmista näkökohdista niin, että omaelämäkerralliset elementit toimivat kerrontaa ja rakennetta muovaavina elementteinä. Suomessa "omaelämäkerrallisen käänteen" vaikutusvaltaisia teoksia ovat muun muassa varhainen 
avainteos Antti Peipon Sijainen (1989) ja Anu Kuivalaisen Orpojen joulu (1994) (Helke 2016, 187). Viime vuosikymmenten aikana omaelämäkerrallisuudesta on myös tullut dokumenttielokuvassa tiettyjen erityisaiheiden ilmaisukeino varsinkin Pohjolan alkuperäiskansoja edustavien elokuvantekijöiden keskuudessa. Ensimmäisen persoonan kertomukset, kuten Liselotte Wajstedtin Sámi nieida jojk (2007) ja Ellen-Astry Lundbyn Min Mors Hemmelighet (Yhtäkkiä saamelainen, 2009), käyttävät omaelämäkerrallisuutta keinona tutkia elokuvantekijöiden saamelaisjuuria.

Elokuvantekijän henkilökohtaisen näkökulman lisäksi kehitys kohti henkilökohtaista kerrontaa on tullut muutenkin dokumenttielokuvissa merkittäväksi piirteeksi. Pohjoismaiden kontekstissa Ezra Winton (2011) laskee määritteen "uuden aallon dokumenttielokuva" Nordisk Panorama - Nordic Short \& Doc Film -festivaalin johtajan Karen Rais-Nordentoftin nimiin. RaisNordentoftin mukaan uusi pohjoismainen dokumenttielokuva on tyylillisesti ja temaattisesti liikkunut kohti humanistista tarinankerrontaa, jossa henkilökohtainen ja poliittinen yhdistyvät. Tälle muutokselle on leimallista siirtyminen dogmaattisesta kohti sosiaalisesti ja poliittisesti hienovaraisempaa elokuvaa, jossa tarkastellaan tosiasioita monimutkaisten henkilökohtaisten kertomusten kautta. (Sit. Winton 2011.) Tällaisissa elokuvissa, kuten Joonas Berghällin ja Mika Hotakaisen Miesten vuoro (2010), henkilökohtaisia tarinoita ja henkilöiden pohdiskeluja käytetään elokuvan rakenteistajina. ${ }^{1}$

Nämä muutokset ovat heijastuneet myös suomalaisen dokumenttielokuvan rahoitukseen, jonka suhteen 1990-luku oli käänteentekevä. "Uuden aallon" dokumenttielokuvan ja laajemmin suomalaisen dokumenttielokuvan kulttuurin tukemisessa keskeisiä ovat olleet Yleisradion, Suomen elokuvasäätiön ja Audiovisuaalisen kulttuurin edistämiskeskuksen strateginen yhteistyö sekä uudet avaukset koulutuspolitiikassa (Sills-Jones \& Kääpä 2016). Näihin uusiin avauksiin liittyy alan koulutus Aalto-yliopiston elokuvataiteen ja lavastustaiteen laitoksella. Sieltä on valmistunut joukko vaikutusvaltaisia dokumenttielokuvan tekijöitä ja tutkijoita, kuten Susanna Helke, joka toteaa:

Jos dokumenttielokuvan projektin perustamisessa on ollut kyse "meidän" tai "kansan" yhteisen äänen luomisesta, niin postmodernista ajasta lähtien, jolloin suuria kertomuksia on karsastettu, "meidän" tarinamme on korvattu identiteettien sirpaleilla, kun dokumenttielokuvan puhuttelutapa varsinkin luovan dokumentin lajityypissä on kytkeytynyt henkilökohtaisiin kokemuksiin. (Helke 2016, 185.)

Monet tämän trendin omaelämäkerrallisista ja henkilökohtaisista lähtökohdista nousevista dokumenttielokuvista vastustavat kollektiivista konsensusta, jota on pidetty lähestymistavaltaan liian ohjailevana ja paternalistisena. Sen sijaan, että nämä uudet dokumenttielokuvat korostaisivat jonkinlaista kollektiivista konsensusta, ne käsittelevät yhteiskunnallisia ja poliittisia aiheita henkilökohtaisten näkökulmien ja kertomusten kautta. Niiden relevanttius perustuu siihen, että ne osoittavat merkittävien poliittisten tapahtumien ja henkilökohtaisten narratiivien välisen suhteen. Elokuvantekijät ammentavat perhehistorioista ja kokemuksistaan valaistakseen suurempia historiallisia ja poliittisia todellisuuksia.

Samalla kun Helke (2016, 191-193) puolustaa omaelämäkerrallisten narratiivien merkitystä henkilökohtaisen ja poliittisen yhdistämisessä, hän kyseenalaistaa omaelämäkerrallisen dokumenttielokuvan trendin, jota hän kutsuu "emotiiviseksi dokumenttielokuvaksi". Helke erottaa tämän suuntauksen muista omaelämäkerrallisista dokumenttielokuvista. Hänen mukaansa
1 Esimerkiksi norjalaiselokuva Barneraneren (Jon Haukeland, 2016) taas tuo elokuvantekijän henkilökohtaisen näkökulman ja aiheen yhteen tavoilla, jotka puhuttelevat kollektiivista kokemusta. 
emotiivinen suuntaus painottaa vähemmän käsittelemiensä aiheiden poliittista tai historiallista kontekstia tarjoamalla sen sijaan omaan napaansa tuijottavan "poliittisen selfien". ${ }^{2}$ Emotiivisesta käänteestä puuttuu syvyys tai rehellisyys, jolla aiemmat omaeläkerralliset dokumenttielokuvat kietoivat henkilökohtaisen ja poliittisen yksityiskohtaisemmin toisiinsa. "Poliittiset selfiet" heijastavat itseään itselleen kuin kaikukammio ja ovat siten oireita uusliberaalista ajasta, jossa minä on kaiken yläpuolella. ${ }^{3}$ Myös Dafydd Sills-Jones ja Pietari Kääpä $(2016,92)$ näkevät nämä muutokset mahdollisina merkkeinä siirtymästä kohti kriittisesti "vähemmän kunnianhimoista" dokumentaarisen elokuvan muotoa.

Lopuksi Helke esittää, että emotiivinen tyyli tarkoittaa ymmärrettävästi myös helpompaa markkinoitavuutta tai suurempaa kaupallista potentiaalia. Koska sen arvo on viihteellisyydessä ja ihmisläheisessä lähestymistavassa, se on houkuttelevampaa Netflixin kaltaisille kaupallisille toimijoille, joiden tarjoama ei-fiktiivinen sisältökin tapaa olla elokuvamaisempaa ja viihteelliseksi dramatisoitua. Helke esittää emotiivisten dokumenttielokuvien ajautuvan itse tähän suuntaan. Tämä on erityisen merkittävä huomio, kun mietimme elokuvateollisuuden tuoreita kehityskulkuja. Esimerkiksi pohjoismaiset tuotantoyhtiöt ovat havainneet "fiktiivisen dokumenttielokuvan" vetovoiman. Suomen Elokuvasäätiön vuoden 2019 katalogin mukaan Made-tuotantoyhtiön tapaiset toimijat "sekä edustavat että muokkaavat itseään uudelleen näiden kehityskulkujen mukaan, joissa dokumentin ja muun elokuvan rajapintaa hämärretään. Kyse on elokuvista, jotka haastavat oman lajityyppinsä ja tarjoavat tekijöiden oman äänen tavoittaakseen niin suomalaiset kuin kansainväliset yleisöt". (Suomen elokuvasäätiö 2019, 36.)

Suomen tapaus osoittaa, että dokumentin eri muotojen ja tarinaelokuvan välillä on yhä vähemmän eroja. Nämä tyylilliset trendit muuttavat käsitystä siitä, miten odotamme dokumenttielokuvan kertovan tärkeistä poliittisista aiheista, kuten Hirvosen elokuvan tapauksessa. Tästä lähtökohdasta Helken taitavat huomiot nykyisestä dokumenttielokuvasta tarjoavat hyödyllisen pohjan Kiehumispisteen eksplisiittisesti poliittisten aiheiden, kuten monikulttuurisuuden, rasismin ja talouskurin käsittelyn tarkastelulle. Tästä huolimatta elokuva myös leikittelee kollektiivisen puhuttelun elementtien ja poliittisen subjektiivisuuden välillä tavoilla, jotka tehostavat ja kehittävät "poliittisen selfien" käsitettä.

Slavoj Žižekin politiikan kulturalisaation teoria (2007) tarjoaa hyödyllisiä välineitä Helken teorian kehittelyyn erityisesti suhteessa pohjoismaiseen näkemykseen tasa-arvosta. Kaksi ilmeisen polarisoivaa narratiivia - suvaitsevaisuus ja maahanmuuttovastaisuus - ilmentävät Pohjoismaiden ideologisen konsensuksen sirpaloitumista. Politiikan kulturalisaatiota tapahtuu varsinkin silloin, kun pyrkimys saada tunnustusta ilmaistaan identiteettitarinoina laajempien sosiopoliittisten ja taloudellisten keskustelujen sijaan. Keskittymällä siihen, miten politiikkaa kulturalisoidaan, Žižek auttaa alleviivaamaan ja selittämään sitä, miten vähemmän "näkyvät" poliittisen ja taloudellisen manipulaation keinot toimivat sosiaaliryhmiä erottavina keinoina.

\section{Kiehumispiste ja äärioikeisto}

Kiehumispiste pyrkii avaamaan Suomessa uudelleen voimistuneen äärioikeiston vihaisia poliittisia narratiiveja, jotka liittyvät kasvavaan maahanmuuttoon ja hyvinvointivaltion heikentämiseen. Hirvonen rakentaa erimielisyyden
2 Pietari Kääpä (2014, 195-197) on toisessa asiayhteydessä kirjoittanut dokumenttielokuvien teosta "egodokumentaarina", jossa tekijän julkkispersoonasta muodostuu määräävä tekijä poliittisesti latautuneiden aiheiden, kuten ympäristönsuojelun, sijaan.

3 Erityisesti brittiläisen Adam Curtisin tuotanto, varsinkin hänen televisiodokumenttinsa The Century of the Self (2002), kuvastaa tätä muutosta. 


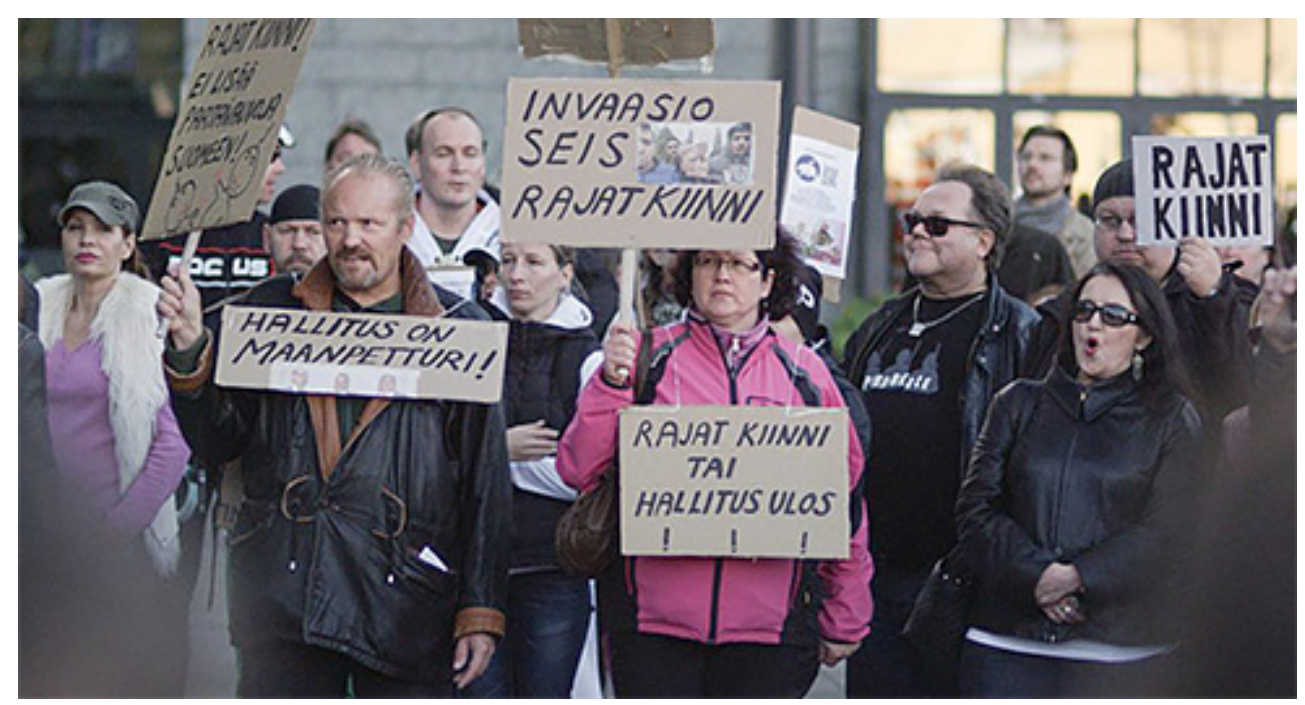

Maahanmuuttokriittiset mielenosoittajat ovat kerääntyneet vaatimaan rajojen sulkemista. Kuva: ruutukaappaus elokuvasta Kiehumispiste.

kahden ääripään, liberaalin maahanmuuttomyönteisyyden ja äärioikeistolaisen maahanmuuttovastaisen populismin ympärille. Tallentaakseen tämän dynamiikan elokuva alkaa kohtauksella Helsingissä pidettävästä mielenosoituksesta, jonka toisella puolella väkijoukko huutaa rasistisia nimityksiä. Toisella puolella maahanmuuttoa tukeva mielenosoitus heiluttaa kylttejä, joissa on surullisen kuuluisa kuva Välimereen vuonna 2015 Syyrian pakolaiskriisin aikana hukkuneesta kolmevuotiaasta Alan Kurdista. Toinen ryhmä huutaa "sulkekaa rajat" ja toinen "avatkaa rajat". Kiehumispisteen ja sen markkinointikampanjan kärkenä on väite, jonka mukaan elokuva esittää vastakkainasettelun molempia osapuolia (ks. Kiehumispisteen kampanjaraportti 2018). Tämän mukaisesti todetaan, että elokuva ei ole eksplisiittisesti ideologinen, vaan se pyrkii välttämään laveat yleistykset ja stereotypiat väittelyn kummallakin puolella. Näin Hirvonen asemoi dokumenttinsa välittämään vastakkaisia, toisinaan lähentyviä identiteettipolitiikkataisteluun jumittuneita näkökulmia.

Kiehumispiste kuljettaa mielenosoitusteemaa läpi elokuvan poliittisesta kokoontumisesta toiseen, mutta elokuvassa on myös useita vakavia "todellisten" ihmisten välisiä keskusteluja. Aloitusotosten jälkeen elokuvassa leikataan Helsinkiin Kotiharjun julkiseen saunaan, jossa kaksi suomalaista miestä, yrittäjä Tapsa ja tutkija Oula, väittelee taannoisesta Suomeen saapuneesta turvapaikanhakijoiden aallosta. Miehillä on aiheeseen vastakkaiset kannat. Oulan mukaan tarvitaan nyansoidumpaa ja faktapohjaisempaa keskustelua, jotta pakolaisten kohtaamat sosiaaliset todellisuudet ja kamppailut sekä monikulttuurisuuden positiiviset ulottuvuudet voitaisiin ymmärtää. Tapsa puolestaan ilmaisee huolensa Suomen tulevaisuudesta ja oletetun etnisen ja kulttuurisen homogeenisuuden säilymisestä. Tämän jälkeen elokuva seuraa nuorta media-aktivistia ja aloittelevaa valokuvajournalistia Jarkko Jaakkolaa tämän omaksuessa Soldiers of Odinin kaltaisten äärioikeistolaisten järjestöjen rasistista propagandaa, jonka tähtäimessä on äärijärjestöjen mieltämä Suomen ja Euroopan "islamisaatio". Propaganda lietsoo pelkoa vastaanottokeskuksissa piileskeleviä Isisin "nukkuvia soluja" kohtaan ja esittää väkivaltarikoksista vääristyneitä käsityksiä, joissa raiskaukset yhdistetään suoraan tekijöiden etniseen identiteettiin (Andersson 2015). 


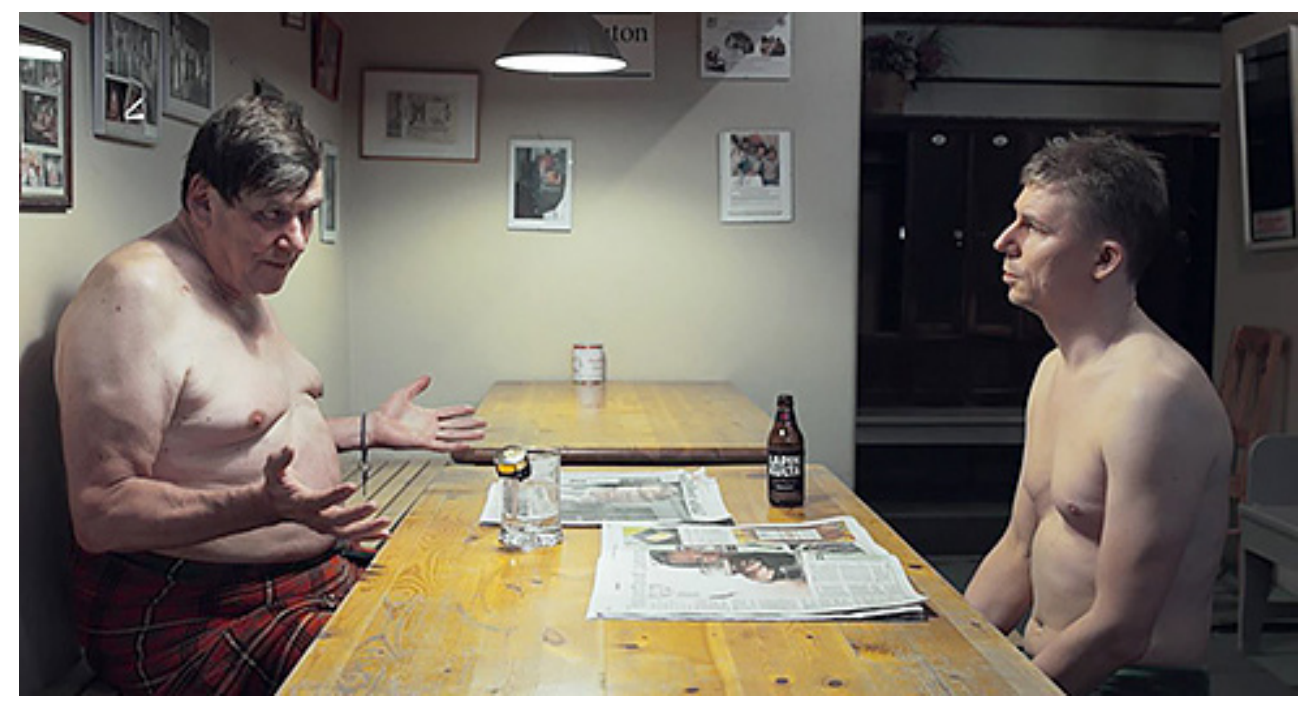

Elokuva tasapainoilee vastakkaisten mielipiteiden välillä: Oula (oikealla) ja Tapsa (vasemmalla) ovat eri mieltä monikulttuurisesta Suomesta. Kuva: ruutukaappaus elokuvasta Kiehumispiste.

Väittelyn toista osapuolta edustaa musta suomalainen aktivisti Suldaan Said Ahmed, joka heiluttaa ylpeästi Suomen lippua rauhanmarsseilla ja kertoo kohtaamistaan rotuennakkoluuloista. Hänen esiintymisensä on kuitenkin verrattain lyhyt. Sama koskee koululaistyttöjä Shahadia ja Tabarakia, kahta syyrialaispakolaista, jotka pakenivat vanhempiensa kanssa ja taistelivat päästäkseen Eurooppaan mutta jotka nyt kokevat väkivallan uhkaa Suomessa. Kerrostalo, jossa he asuvat, on joutunut murhapolttoyrityksen kohteeksi. Maahanmuuttajille perustetussa keskuksessa Kemissä osa-aikaeläkkeellä oleva Liisa Puupponen opettaa suomea ja yrittää auttaa kahta turvapaikanhakijaa, Nawrasia ja Mohamedia, joiden turvapaikkahakemukset on hylätty. Vaikka Puupponen tekee parhaansa, miehet vajoavat masennukseen, antavat periksi ja näyttävät katoavan hämärään.

Kiehumispisteen keskittyminen äärioikeiston nationalismiin saa erityisen kaiun, koska elokuva ilmestyi norjalaisen Anders Breivikin karmean perinnön varjossa. Breivikin, äärioikeistolaiseksi julistautuneen ekstremistin, tekemä sarja pommi- ja aseiskuja Norjan työväenpuoluetta ja sen nuorisosiipeä vastaan vuonna 2011 on Pohjoismaille ja laajemmin Euroopalle yksi pohjoismaista nationalismia koskevien akateemisten väittelyiden kiintopisteistä. Breivikin ennenäkemättömissä iskuissa Oslossa ja pienellä Utøyan saarella kuoli 77 ihmistä, joista suurin osa oli teini-ikäisiä. Yksi Breivikin päätavoitteista oli puolustaa pohjoismaista valkoista ylivaltaa, koska hän koki islamin uhkaavan niin Norjaa kuin muitakin länsimaita. Vastaavasti vuoden 2015 pakolaiskriisin aikaan Suomessa nähtiin rasistisesti motivoitua väkivaltaa, kuten laajalti tuomitut iskut pakolaisia, irakilaisia turvapaikanhakijoita kuljettanutta bussia ja Punaisen Ristin työntekijää vastaan. Noin neljänkymmenen mielenosoittajan joukossa oli yksi, joka heilutti Suomen lippuja Ku Klux Klan -asusteisiin pukeutuneena (YLE 2015). Vaikka Kiehumispiste ei suoraan viittaa Breivikiin, se dokumentoi maahanmuuton ympärillä olevia eripuran ja sosiaalisen jännittyneisyyden tuntemuksia. Tästä huolimatta se jättää nämä tietyt, pääosin nuorten miesten tekemät teot käsittelemättä. 


\section{Talouskurin merkitykset Kiehumispisteess $\ddot{a}$}

Kiehumispisteen dialogiin perustuva kerronta jättää monta asiaa sanomatta. Yksi sivuutettu asia on talouskurin kattava tarkastelu sosiaalisen jaon ja rotuvihan keskeisenä laukaisijana. Vaikka elokuva keskittyy vahvistamaan etnisten ja kulttuuristen jakolinjojen molemmille puolille sijoittuvien marginalisoitujen ihmisten näkökulmia, se myös viittaa laajempaan, sosiopoliittisia konteksteja koskevaan politiikkaan. Tämä narratiivi pureutuu erityisesti talouskurin viimeaikaiseen historiaan Suomessa. Huolimatta sen vaurautta korostavista ja utooppisista mielikuvista, talouskurin politiikka on hallinnut perättäisten uusliberalististen hallitusten aikakaudella erityisesti 1990-luvun lamasta alkaen.

Vaikka niin sanottu pohjoismainen malli toimii edelleen tavoiteltuna kiintopisteenä alueen ulkopuolisille talouksille, sosiologit, kuten John Roemer ja Pranab Bardhan (1992), ovat kritisoineet hyvinvointivaltioon tehtyjä rakenteellisia ja ideologisia muutoksia. He kritisoivat avoimesti siirtymää kohti uusliberalistisia intressejä 1980-luvulla, mitä he pitävät käännekohtana alueen sosioekonomisessa historiassa, ja osoittavat, että vapaiden markkinoiden sosiaalisia olosuhteita muokkaava malli on perustavanlaatuisesti ristiriidassa hyvinvointivaltion valtio-orientoituneen eetoksen kanssa. Radikaaleimmat muutokset pohjoismaiseen hyvinvointimalliin tapahtuivat, kun "kansainvälisen kilpailuyhteiskunnan paradigma" tuli agendaksi 1980-luvulla (Kananen 2014, 164). Tällöin siirryttiin priorisoimaan sosiaalisten ja julkisten intressien sijaan taloudellista kunnianhimoa, kansainvälistä markkinakilpailua, yksityistämistä sekä asteittaista, joskin epätasapainoisesti kohdistettua talouskuria. Kanasen (ibid.) mukaan siirtymät kohti yksityisiä intressejä ovat vahingoittaneet hyvinvointivaltion infrastruktuuria ja nakertavat edelleen sen tasavertaisuudelle perustuvia arvoja.

Anna Elomäki ja Johanna Kantola (2017) toteavat, ettei Suomen talouskurinarratiivissa ole kyse vain pragmaattisesta vastauksesta globaaleihin finanssipaineisiin, vaan sitä pönkittää myös ideologinen asenteellisuus markkinoita kohtaan. Heidän mukaansa tällaisilla keinoilla on myös rodullinen ulottuvuus (ibid, 234), mikä on merkittävää, sillä talouskuri viittaa juurtuneeseen epätasaarvoa tuottavaan rakenteeseen, joka sekä lisää että toisintaa etnisiä eroja.

Kiehumispiste paljastaa erityisesti sen, miten äärioikeistolaiset ryhmät käyttävät "hyvinvointisovinismia" (ks. Andersen \& Bjørklund 1990) pönkittämään omaa identiteettiään. ${ }^{4}$ Hyvinvointisovinistisesta "Suomi ensin"-ajattelusta on tullut mantra, joka on osa heidän taisteluhuutoaan kokemaansa ulkopuolisten tunkeutumista vastaan. Hyvinvointivaltion "koskemattomuuden" suojelusta on tullut vuoden 2015 pakolaiskriisin myötä yhä tärkeämpi teema. Tulokkaat nähdään suorana uhkana tilanteessa, jossa "taloudellinen niukkuus", kuten Maria Hokkinen $(2019,112)$ asian ilmaisee, on jo valmiiksi ongelma. Äärioikeistolaiset liikkeet ovat käyttäneet tilannetta hyväkseen väittämällä, että julkiset palvelut ja varat kuuluvat vain "alkuperäisille" suomalaisille. Kiehumispiste vahvistaa näitä uskomuksia otoksilla äärioikeiston kokoontumisista, joissa puhuu useita tunnettuja maahanmuuttovastaisia kriitikoita. Nämä otokset, joita Hirvonen käyttää läpi elokuvan, palvelevat kahta tarkoitusta. Yhtäältä ne muodostavat ironisia rinnastuksia äärioikeiston toksisen retoriikan ja radikaalin islamistisen ekstremismin välille niin, että ne tuntuvat samalta asialta.

Toiseksi nämä kohtaukset auttavat luomaan yhteyksiä Kiehumispisteen laajempaan kontekstiin eli heikentyneeseen hyvinvointivaltioon. Äärijärjestöjen
4 Jørgen Goul Andersen ja Tor Bjørklund käyttävät hyvinvointisovinismia luonnehtimaan tapaa, jolla pohjoismaiset oikeistopopulistiset ryhmät kannattavat sosiaaliturvan rajaamista syntyperäisille kansalaisille. 


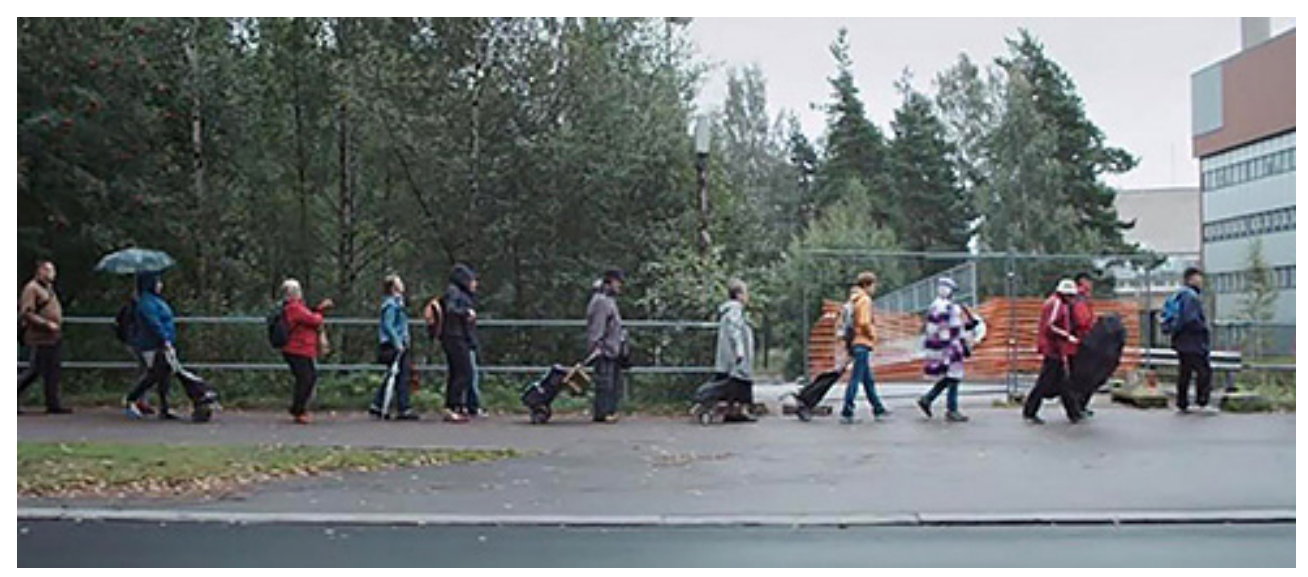

Leipäjono Helsingissä. Kuva: ruutukaappaus elokuvasta Kiehumispiste.

kokoontumisia kuvaavien otosten joukkoon leikataan staattisia kuvia Helsingin ruokapankkiin jonottavista ihmisistä. Näiden kuvien aikana kuulemme suomalaisen miehen kertovan maahanmuuton aiheuttamista peloistaan ja turhautumisistaan. Elokuva antaa kuitenkin ymmärtää, että hänen huolensa ovat seurausta siitä, että hänen oma köyhyytensä on vääristänyt hänen käsityksensä taloudellisesta epätasa-arvosta. Hän ei ilmaise mitään pelkoa siitä, että kulttuurinen homogeenisuus olisi uhattuna. Sen sijaan hänen maahanmuuttajavastaisuutensa perustuu oletukseen, jonka mukaan hyvinvointivaltio suosii maahanmuuttajia kohtuuttomasti sosiaalituissa.

Koska köyhyyttä ja ruokapankkeja ei tavallisesti assosioida hyvinvointivaltio Suomeen, Hirvosen ratkaisu tuoda nämä lyhyet katkelmat kiihkoisänmaallisen retoriikan kontekstin rinnalle nakertaa vahvasti Suomen tasavertaisuuteen pyrkivän sosioekonomisen imagon laajempaa kertomusta. Elokuva kuitenkin myös näyttää, miten jatkuvien leikkausten ja kasvavan työttömyyden nostamat pelot manifestoituvat kulttuurisella tasolla lietsoen vihaa ja vastakkainasettelua etnisten ryhmien välillä. Ruokapankkeja on toiminut Suomessa 1990-luvun turbulenteista vuosista alkaen, ja väittelyt siitä, ansaitsevatko maahanmuuttajat hyvinvointipalveluja vai eivät, hallitsevat yhä julkista keskustelua. Tutkimuksessaan, joka käsittelee ruoka-avun saajien näkemyksiä, Anna Sofia Salonen, Maria Ohisalo ja Tuomo Laihiala (2018) saivat selville, että avun ansaitseminen kyseenalaistettiin varsinkin silloin, kun ruoka-avun saajat eivät kuuluneet vastaajan kanssa samaan sosiaaliryhmään. Vastaavasti kommentoijat korostivat omaa vastuullisuuttaan. Kaikkein ehdollisimmin suhtauduttiin maahanmuuttajataustaisiin ruoka-avun saajiin.

\section{Kiehumispisteen henkilöhahmojen ongelmallisuus}

Polarisoituneiden aiheiden käsittelystä huolimatta Hirvosen pääteema on dialogin rakentaminen. Kiehumispiste saavuttaa päämääränsä vuoropuhelua painottamalla, sillä dialogi on läpi elokuvan kulkeva teema, ja sitä käytettiin myös elokuvan markkinointikampanjassa. Kiehumispiste asetettiin heti julkaisunsa jälkeen vapaasti katsottavaksi, mikä korostaa sen luonnetta dialogiin kannustavana työnä. Elokuvassa dialogisuus tulee parhaiten esille Oulan ja Tapsan keskusteluissa, jotka käydään osuvasti saunan "kansallisessa" tilassa. Miesten vastakkaiset mielipiteet maahanmuuttajista avaavat eräänlaisen 
sosiaalisen jakaantumisen "juonikuvauksen". Tapsa on huolissaan maahanmuuttajien auttamisen taloudellisista kustannuksista. Oula taas on sitä mieltä, että Suomen kaltaisilla rikkailla mailla on moraalinen ja sosiaalinen velvollisuus ulkopuolisia kohtaan. Hirvonen (sit. Martens 2017) on itse asiassa todennut, että hän näkee Oulan ja Tapsan keskustelut saunassa elokuvansa keskusajatuksen todellisena ytimenä: ihmiset voivat olla yhteisymmärryksessä eri mieltä ilman kestävää vihamielisyyttä tai jakaantumista.

Oulan ja Tapsan keskustelujen sijoittaminen saunaan on tietysti tarkoituksellinen ratkaisu, koska sauna liitetään tilana suomalaiseen kansalliseen identiteettiin. Tila edesauttaa dialogin syntymistä: mielipiteiden polarisaatio tulee selväksi, mutta keskustelun sävy on rakentava ja diplomaattinen. ${ }^{5}$ Dialogisuus rakentuu kuitenkin myös piilevälle draaman tunnulle, mikä on seurausta lippuja heiluttavien mielenosoittajien ja Suldaanin kaltaisten rauhanaktivistien välisistä jännitteistä. Jokainen haastateltu on oma äänensä tarinassa, joskaan nämä äänet eivät ole välttämättä edustavia. Kiehumispisteen dialogia on tarkasteltava kriittisesti sekä tältä kannalta että siinä suhteessa, kuinka laajalti se käsittelee maahanmuuton vaikeampia kysymyksiä. Ensi silmäyksellä elokuva näyttää kuvaavan äärioikeiston fanatismin kantoja tasapainoisesti. Se ei ihannoi mutta ei myöskään täysin sivuuta niitä. Se kehystää äärioikeiston rasismin seuraukseksi väärin suunnatusta lojaalisuudesta kuvitteellista kansallista yhteisöä kohtaan. Kyseessä on narratiivi, joka on noussut esiin ympäri maailmaa Trumpista Brexitiin. Elokuva paljastaa erityisesti sen, miten äärioikeisto pyrkii radikalisoimaan aiemmin mainitun Jaakkolan kaltaisia, haavoittuvassa tilassa olevia ihmisiä, jotka kokevat, että heiltä on viety ääni. Elokuva näyttää äärioikeiston toiminnassa ja poimii tehokkaasti erilaisten kehityskulkujen yksityiskohtia, kuten nationalistisesti orientoituneiden kampanjoiden ja yksilöiden taitavaa imagonsa epäpolitisointia, jolla tavoitellaan suurempien väestönryhmien suosiota. Näin Kiehumispiste korostaa, miten äärioikeiston politiikan rasistista pohjaa on viime aikoina pyritty naamioimaan.

Toisaalta Kiehumispiste ei pohdi kriittisesti maahanmuuton laajempia seurauksia Suomelle, eikä siinä esiinny maahanmuuttajia, joilla on rikosrekisteri tai tuomioita, tai ylipäätään ketään, joka ei edusta laajasti medioitua kuvaa maahanmuuttajista "uhreina". Tällä etäännytyksellä on huomattavat seuraukset, sillä näin maahanmuuttajista ja pakolaisista muodostuu homogeeninen ryhmä, jota määrittää passiivinen haavoittuvaisuus. Ensinnäkin pakolaisten määrittäminen passiivisiksi uhreiksi nakertaa heidän toimijuuttaan. ${ }^{6}$ Toinen ongelma elokuvassa on sen binaarinen tapa ymmärtää pakolaiset "hyvinä uhreina" ja maahanmuutosta huolestuneet valkoiset suomalaiset rasisteina. Näin elokuva ei onnistu porautumaan monikulttuurisuuden todellisten esteiden läpi. On ymmärrettävää, että Hirvonen valikoi esittämänsä maahanmuuttajat, sillä painottamalla näiden haavoittuvaisuutta hän kykenee vankistamaan dokumenttinsa perustana olevaa eetosta, joka korostaa suvaitsevaisuutta ja toisten hyväksymistä. Raflaavampien teemojen pois jättäminen johtaa siihen, että dialogi ei ole avointa vaan pikemminkin tuotettu luomaan illuusio mielipiteenvaihdosta. Tällainen lähestymistapa tuntuu ennemmin markkinoivan sitä, että Kiehumispiste edustaa jotain poikkeuksellista itsessään, dokumenttina, kuin tutkii rodullisen eriarvoisuuden ja sosiaalisen marginalisoimisen nyansseja yhteiskunnassa.
5 On huomattavaa, että miesten alastomuudella on symbolinen merkitys. Alastomuus alleviivaa heidän mielipiteidensä läpinäkyvyyttä, mikä taas vahvistaa elokuvan sanomaa avoimuudesta. Mukana on kuitenkin myös toisenlainen konnotaatio, sillä sauna assosioituu suomalaisessa kulttuurissa myös poliittisten neuvotteluiden tilaksi. Elokuvassa keskustelun poliittisiin aspekteihin tulee tunteellinen ulottuvuus, sillä saunakohtauksia edeltävät otokset molempien osapuolien tunteenpurkauksista mielenosoituksissa.

6 Yksityiskohtaisista maahanmuuttajarepresentaatioista suomalaisessa elokuvassa ks. Ballesteros 2015, 163-167; Hiltunen 2016, 235-253. 


\section{"Poikkeuksellinen" dialogi, yksilöllinen valinta ja "politiikan kulturalisaatio"}

Kiehumispistettä ei voi tarkastella täysin ongelmattomasti suhteessa Helken emotiivisen dokumenttielokuvan teoriaan, koska siinä tuodaan kuitenkin jossain määrin esiin laajempia poliittisia rakenteita. Elokuva nimittäin vihjaa, että niukkuudella on haitallinen vaikutus ihmisten näkemyksiin maahanmuutosta. Näin elokuva samassa myös toteaa, että poliittisilla päätöksillä on vaikutusta yleiseen mielipiteeseen. Tämän vuoksi elokuva itse asiassa kyseenalaistaa ajatuksen siitä, että maahanmuuttovastaiseen politiikkaan olisi mahdollista löytää ratkaisu puhtaasti yksilöiden emotionaalisten kohtaamisten kautta. Tätä rakenteellisen tason tarkastelua ei kuitenkaan viedä tarpeeksi pitkälle. Loppujen lopuksi elokuvan narratiivin voi sanoa heijastelevan yksilökeskeisyyttä. Tämä näkyy selvästi kohtauksissa, joissa Suldaan Said Ahmed ja Odinin sotureiden jäsenet kohtaavat mielenosoituksen yhteydessä. Kuten Oula ja Tapsa dialogissaan, hekin kunnioittavat toisiaan ja käyvät lyhyen mutta suorapuheisen keskustelun eroavaisuuksistaan. Kohtaaminen ei ole niin hyökkäävä kuin voisi odottaa sen perusteella, että elokuvassa on jo nähty rasismin saavan aggressiivisia piirteitä oikeiston muissa joukkokokoontumisissa. Näiden kohtausten tarkoituksena vaikuttaakin olevan aiemmin rakennettujen jännitteiden purkaminen.

Tarkemmin katsottuna keskustelu on kuitenkin ongelmallinen, koska osapuolet pitävät politiikan rakenteellisia vaikutuksia identiteetteihin itsestään selvänä. Keskustelu synnyttää vaikutelman, että yksilö voi henkilökohtaisen päätöksensä perusteella ryhtyä dialogiin eri mieltä olevan kanssa. Tämä antaa ymmärtää, että mikäli erimieliset kykenevät neuvottelemaan identiteettikysymyksistä rakentavassa hengessä, he pystyvät myös parantamaan yhdessä elämisen mahdollisuuksia yhteiskunnassa. Elokuvassa keskusteluja ohjaavat kuitenkin tunteet sen sijaan, että siinä käsiteltäisiin yhteiskunnan jakaantumiseen vaikuttavia poliittisia tekijöitä. Ja kuten aiemmin totesin, keskustelun luonteeseen vaikuttavat myös Hirvosen elokuvaan valitsemat toimijat.

Nämä toimijat auttavat vahvistamaan dokumentin ei-ideologista näkökantaa. En kiistä, etteikö dialogilla olisi keskeinen rooli rasismin purkamisessa ja haastamisessa, mutta ongelma on jälleen kerran siinä, minkälainen merkitys

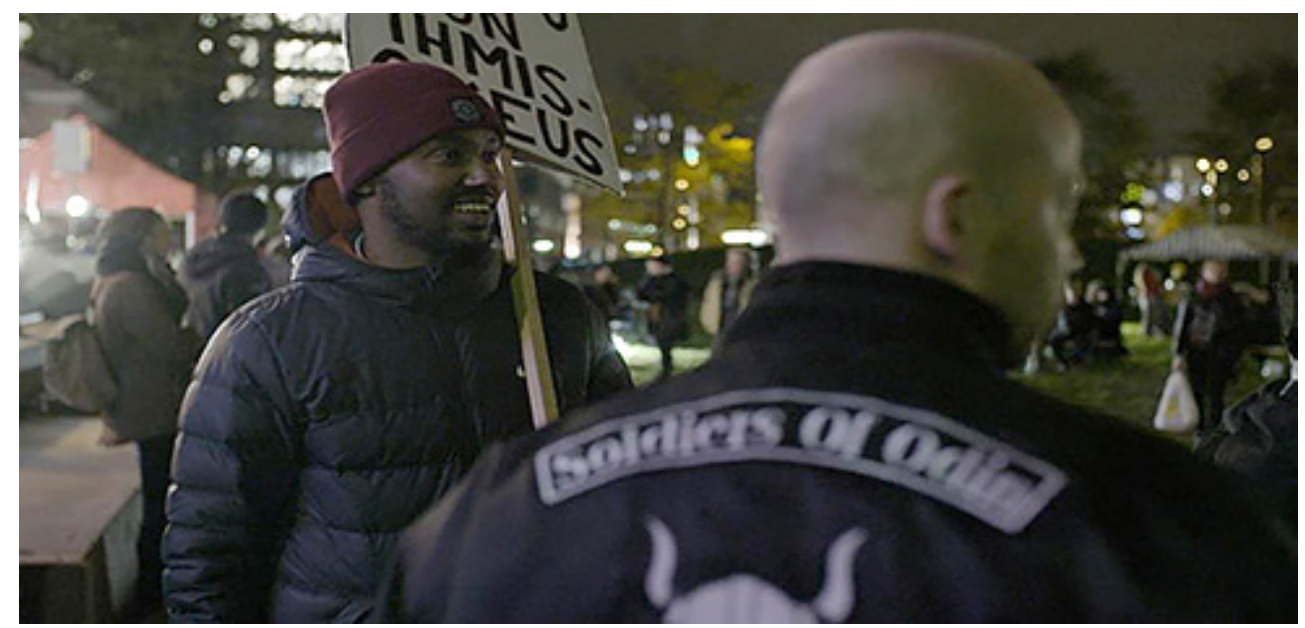

Vastakkaiset näkemykset dialogissa. Kuva: Ruutukaappaus elokuvasta Kiehumispiste. 
poliittiselle kontekstille annetaan. Kiehumispiste turvautuu identiteettipolitiikkaan osoittaakseen, että yksilöt tekevät valintoja ja pystyvät käymään dialogia. Se ei varsinaisesti tutki sitä, millä tavoin ulkoiset poliittiset ja ideologiset tekijät toimivat tämän dialogin edellytyksenä. Emotiivisen käänteen jälkeisistä dokumenttielokuvista Helke toteaa:

Vaikka nämä elokuvat väittävät olevansa poliittisia, niiden ehdottama poliittisuus on peräisin liberalistisesta yksilön vapauden - ja yksilön velvollisuuden - ihanteesta, joka ei huomioi, että sitä universumia, jossa pystymme tekemään valintoja, määrittävät makropoliittiset ja taloudelliset voimat (Helke 2016, 192).

Tämä kumoaa väittelyn ytimen, sillä samaan tapaan kuin poliittiset selfiet, Kiehumispiste sivuuttaa uusliberalismin politiikan ja korostaa sen sijaan yksilön asemaa. Elokuva osoittaa, että kun identiteettipolitiikasta tulee pääasia, hallitsevasta ideologisesta narratiivista jää puuttumaan syvempi kriittinen tarkastelu. Näin elokuva kadottaa poliittisen kontekstin, jonka avulla olisi mahdollista selittää, miten jakolinjat ovat syntyneet ja ehkä vielä kriittisemmin, miten talouskurinarratiivi hyötyy näistä jakolinjoista.

Vaikka jotkut haastateltavista kannattavat rasistisia ideologioita, elokuva antaa lopulta kuitenkin optimistisen vaikutelman kahdesta vastakkaisesta osapuolesta, jotka päättävät yhteisymmärryksessä olla eri mieltä. Elokuvassa dialogien pääpuheenaiheeksi nousee suvaitsevaisuus, joka nähdään henkilökohtaisena valintana. Žižek (2007) kyseenalaistaa suvaitsevaisuuden, koska hän pitää sitä lähtökohtaisesti latautuneena ja ideologisena käsitteenä, joka antaa syvään juurtuneen rasismin olla ja joka jättää huomioimatta taloudellisella ja poliittisella tasolla vallitsevan epätasa-arvoisuuden ja epäoikeudenmukaisuuden. Žižekin (ibid., 660) mukaan liberaaleja länsimaisia yhteiskuntia ohjaa erityinen tapa reagoida ennakkoluuloihin: "Liberaalin monikulturalistin reaktio on alkeellisen ideologinen: 'politiikan kulturalisaatio' eli poliittisten erojen, poliittiseen epätasa-arvoon liittyvien erojen, taloudellisen hyväksikäytön, ynnä muiden luonnollistaminen 'kulttuurisiksi' eroiksi, erilaisiksi 'elämäntavoiksi' . Nämä erot otetaan annettuina, jolloin niitä ei voi selvittää vaan ainoastaan 'suvaita'"'.

Monikulttuurisuutta ovat kritisoineet myös ne, joiden mielestä käsite nojaa yksinkertaistettuihin käsityksiin eri ryhmistä. Esimerkiksi Elisabeth Eide ja Kaarina Nikunen $(2011,6)$ huomauttavat, että "monikulttuurisuudella on erityisiä ulottuvuuksia pohjoismaisessa kontekstissa, jossa yhteiskunnilla on ajateltu olevan enemmän tai vähemmän homogeeninen koostumus", ja että "käsitys yhdestä kansasta on juurtunut syvään pohjoismaisten kansallisvaltioiden kertomuksiin". Pohjoismaisessa kontekstissa monikulttuurisuuden ja hyvinvointi-ideologian lähentymisen myötä esiin nousevia ristiriitaisia dynamiikkoja tarkastelevien Peter Kivistön ja Östen Wahlbeckin $(2013,327)$ mukaan kysymys on siitä, "onko erilaisuuksien hyväksymiseen perustuva inkluusion malli epäsopiva demokraattisiin hyvinvointiyhteiskuntiin, jotka on historiallisesti määritelty universalismin periaatteiden mukaisesti". Heidän analyysinsa siis korostaa, että samankaltaisuuden eetokselle perustuva hyvinvointivaltio ja erilaisuudelle perustuva monikulttuurisuus ovat toisensa poissulkevia.

Žižekin (1997) mukaan monikulttuurisuuden toteutuminen riippuu siis Toisesta, jonka tulisi käyttäytyä länsimaisten odotusten mukaisesti. Jos Toinen ei mukaudu odotuksiin, ei tasa-arvoisuus toteudu. Monikulttuurisuus on noussut valtaideologiasta keinoksi torjua kulttuurista ulossulkemista. Žižekin 
tulkinnan mukaan länsimaiden odotukset perustuvat kuitenkin siloteltuun ja homogeeniseen käsitykseen Toisesta, jossa ei ole tilaa antagonismille, kompleksisuudelle ja ristiriidoille. Juuri tätä vaikutelmaa Kiehumispiste vahvistaa. Lisäksi, vaikka väitän, että Kiehumispiste hylkää kaiken kattavat ideat, kuten monikulttuurisuuden, juuri tämänkaltaiseen representaatioon se valikoivan dialoginsa vuoksi nojaa.

Kiehumispisteen tapauksessa emotiivisen käänteen mukainen dokumentaarisuus edesauttaa kulturalisaation prosessia vahvistamalla suvaitsevaisuuteen ja ymmärrykseen liittyvää ajattelua. Suvaitsevaisuuden narratiivilla on kuitenkin oma ideologinen katsantokantansa, joka painottaa yksilöiden henkilökohtaisia mielipiteitä ja näkemyksiä eroista, mutta ei ota huomioon laajemman poliittisen diskurssin vaikutusta näihin mielipiteisiin. Elokuva esittää lopulta optimistisesti, kuinka keskustelun vastakkaiset osapuolet päättävät olla eri mieltä. Todellinen sovinnollinen dialogi syntyykin sopuisan erimielisyyden kuvauksen ja elokuvan velvollisuutenaan pitämän vakavien yhteiskunnallisten kysymysten käsittelemisen ja tasa-arvon edistämisen välille. Sen, että elokuvan yhteiskunnallinen tietoisuus heijastaa jaettuja (ideologisia) arvoja Suomesta "poikkeuksellisena" yhteiskuntana, joka on avoin kaikenlaisille näkemyksille, voikin myös tulkita ironisesti.

\section{Päätäntö}

Susanna Helken $(2016,184)$ mukaan dokumenttielokuvassa on tapahtunut tyylillinen siirtymä "vahvasta kollektiivisen retorisen puhuttelun konventiosta" subjektiivisempaan ja poliittisesti vähemmän tarkkanäköiseen puhutteluun. Tuloksena on Helken mukaan "emotiivinen dokumenttielokuva", jossa henkilökohtaiset valinnat, kamppailut ja tunteet nousevat keskeisiksi kerronnan keinoiksi. Emotiivinen käänne edustaa näkemykseni mukaan sitä, mitä Žižek kuvaa kulturalisaatioksi. Kiehumispiste tuo kerronnan keskiöön kulttuurisia eroja koskevat ongelmat ja ehdottaa, että yksilön itsereflektio on järkevin tapa neuvotella näistä eroista. Tämä tapahtuu kuitenkin monimutkaisempien poliittisten tai taloudellisten kysymysten kustannuksella.

Elokuva vihjaa taustalla vaikuttaviin laajempiin poliittistaloudellisiin hierarkioihin lyhyillä kohtauksilla Helsingin ruokapankeista. Näiden kuvien kautta tehdään näkyväksi yhteys resurssien kiristämisen ja taloudellisen tasapainon horjuttamisesta syytettyjen maahanmuuttajien välille. Kuitenkin ne hetket, joissa annetaan ymmärtää, että Suomen talouskurinarratiivi on ruokkinut rodullisia ennakkoluuloja, jäävät lyhykäisiksi. Tämä on ongelmallista, koska talouskuripolitiikan ideologia on tärkeä kiila eri sosioekonomisten ja etnisten ryhmien välissä. Väheksymällä hierarkioiden merkitystä Kiehumispiste antaa kiillotetun kuvan todellisuudesta ja asettuu yksilöllistä valintaa painottavan narratiivin puolelle. Sen mukaan yksilöllisessä valinnassa, päätöksessä olla eri mieltä, päätöksessä auttaa pakolaisia, päätöksessä osallistua äärioikeistolaiseen liikkeeseen, on nimenomaan kyse valinnasta. Siinä yksilöt muokkaavat narratiivin tarkoitusta ja suuntaa eivätkä poliittiset rakenteet, jotka yksilön valintoja ennalta määräävät. Poliittisen ketjun yläpäässä olevat toimijat ja ideologiat jäävät anonyymeiksi. Heidän asemaansa tilanteen vastuullisina osapuolina olisi syytä tutkia lisää. 


\section{Lähteet}

\section{Elokuvat}

Berghäll, Joonas \& Hotakainen, Mika (2010) Miesten vuoro. Suomi: Oktober Oy/Rode Orm Film AB.

Curtis, Adam (2002) The Century of the Self. Iso-Britannia: BBC.

Haukeland, Jon (2016) Barneraneren. Norja: Medieoperatørene AS.

Helke, Susanna (2010) Leikkipuisto. Suomi: For Real Productions.

Hirvonen, Elina (2017) Kiehumispiste. Suomi: Mouka Filmi Oy.

Kuivalainen, Anu (1994) Orpojen joulu. Suomi: University of Art and Design Helsinki.

Lundby, Ellen-Astry (2009) Min Mors Hemmelighe. Norja: Ellen Lundby Film \& Media.

Peippo, Antti (1989) Sijainen. Suomi: Verity Films.

Wajstedt, Liselotte (2007) Sámi nieida jojk. Ruotsi: LittleBig Productions.

\section{Kirjallisuus}

Alexandru, Vlad (2019) Visual Symbolism and the Poetic Documentary. International Multidisciplinary Scientific Conference on the Dialogue between Sciences $\mathcal{E}$ Arts, Religion E Education vol. 3:3, 56-63.

Andersen, Jørgen Goul \& Bjørklund, Tor (1990) Structural Change and New Cleavages: The Progress Parties in Denmark and Norway. Acta Sociologica vol 33:3, 195-217.

Andersson, Maja-Stina (2015) Invandrarbakgrund förklarar inte brottslighet. HBL.fi. Saatavilla: $<$ http://gamla.hbl.fi/nyheter/2015-12-02/780723/invandrarbakgrund-forklarar-inte-brottslighet> (linkki tarkistettu 18.11.2020).

Ballesteros, Isolina (2015) Immigration Cinema in the New Europe. Bristol: Intellect.

Bałaga, Marta (2019) The Finnish Film Foundation Makes Sure Different Stories Are Told. Cineuropa.org. Saatavilla: <https://cineuropa.org/newsdetail/369552/> (linkki tarkistettu 18.11. 2019).

Bardhan, Pranab \& Roemer, John. E. (1992) Market Socialism: The Current Debate. Oxford: Oxford University Press.

Bordwell, David (2007) Poetics of Cinema. London: Routledge.

Browning, Christopher S. (2007) Branding Nordicity: Models, Identity and the Decline of Exceptionalism, Cooperation and Conflict. Journal of the Nordic International Studies Association vol. 42:1, 27-51.

Eide, Elisabeth \& Nikunen, Kaarina (2011) Introduction: Change of Climate. Teoksessa Elisabeth Eide \& Kaarina Nikunen (toim.) Media in Motion: Cultural Complexity and Migration in the Nordic Region. Farnham: Ashgate, 1-19.

Elomäki, Anna \& Kantola, Johanna (2017) Austerity Politics and Feminist Resistance in Finland: From Established Women's Organizations to New Feminist Initiatives. Teoksessa Johanna Kantola \& Emanuela Lombardo (toim.) Gender and the Economic Crisis in Europe. Baisingstoke: Palgrave Macmillan, 231-257.

Haase, Antti (2016) The Golden Era' of Finnish Documentary Film Financing and Production. Studies in Documentary Cinema vol. 10:2, 106-129.

Helke, Susanna (2016) In Pursuit of Emotions: The Emotive Turn and Postpolitical Sentiment in Finnish Documentary Film Culture. Studies in Documentary Film vol. 10:2, 183-197.

Helke, Susanna (2013) Sacred, Mundane and Absurd Revelations of the Everyday - Poetic Vérité in the Eastern European Tradition. Teoksessa Brian Winston (toim.) The Documentary Film Book. London: BFI, 247-254.

Hiltunen, Kaisa (2016) Encounters with Immigrants in Recent Finnish Feature Films. Journal of Scandinavian Cinema vol. 6:3, 235-253.

Hokkinen, Maria (2019) Unacceptable Consumption: Conflicts of Refugee Consumption in a Nordic Welfare State. Teoksessa Søren Askegaard \& Jacob Östberg (toim.) Nordic Consumer Culture: State, Market and Consumers. Basingstoke: Palgrave Macmillan, 95-118. 
Jääskeläinen, Jarmo (2013) Interview by Dafydd Sills-Jones. Helsinki, February.

Kananen, Johannes (2014) The Nordic Welfare State in Three Eras: From Emancipation to Discipline. Farnham: Ashgate.

Kiehumispisteen kampanjaraportti (2018) Kiehumispiste. Saatavilla: <http://mouka.fi/wp-content/uploads/2018/04/Kiehumispisteen-kampanjaraportti.pdf $>$ (linkki tarkistettu 21.12.2019).

Kiilakoski, Tomi \& Oksanen, Atte (2011) Cultural and Peer Influences on Homicidal Violence: A Finnish Perspective. New Dir Youth Dev. vol.129, 31-42.

Kivisto, Peter \& Wahlbeck, Östen (2013) Reflections on the Future of Multicultural Inclusion in the Nordic Countries. Teoksessa Peter Kivisto \& Östen Wahlbeck (toim.) Debating Multiculturalism in the Nordic Welfare States. Basingstoke: Palgrave Macmillan, 325-339.

Kääpä, Pietari (2014) Ecology and Contemporary Nordic Cinema. London: Bloomsbury.

Kääpä, Pietari \& Moffat, Kate (2018) Unthinking Ethnocentrism: Ecocritical Approaches to Ethnic Diversity in Nordic Screen Media. Journal of Scandinavian Cinema vol. 8:2, 149-165.

Marten, Peter (2017) Finnish Documentary Builds Dialogue, Not Division. This is Finland. Saatavilla: <https://finland.fi/arts-culture/finnish-documentary-builds-dialogue-not-division/> (linkki tarkistettu 13.4.2020).

Pitcher, Ben (2014) Consuming Race. London: Routledge.

Salonen, Anna Sofia; Ohisalo Maria \& Laihiala, Tuomo (2018) Undeserving, Disadvantaged, Disregarded: Three Viewpoints of Charity Food Aid Recipients in Finland. International Journal of Environmental Research and Public Health vol. 15:12, 1-15.

Sills-Jones, Dafydd \& Kääpä, Pietari (2016) The Finnish Documentary: A Critical Overview of Historical Perspectives and Thematic Developments. Studies in Documentary Film vol. 10:2, 89-105.

Smith, Helena (2015) Shocking Images of Drowned Syrian Boy Show Tragic Plight of Refugees. The Guardian. Saatavilla: <https://www.theguardian.com/world/2015/sep/02/shocking-imageof-drowned-syrian-boy-shows-tragic-plight-of-refugees> (linkki tarkistettu 30.8.2020).

Suomen elokuvasäätiö (2019) Finnish Film Industry 2019. SES, The Finnish Film Foundation. Saatavilla: <https://ses.fi/fileadmin/dokumentit/finnish-film-industry-DIGI.pdf> (linkki tarkistettu 3.8.2020).

Winton, Ezra (2011) New Nordic Documentary Cinema Making Identity Visible. Point of View Magazine. Saatavilla: <http://povmagazine.com/articles/view/new-nordic-documentary-cinema> (linkki tarkistettu 17.8.2020).

Woodhead, Hannah (2018) Real-Life Terror: Is it Exploitative to Use Human Suffering for Cinematic Thrills? The Guardian. Saatavilla: <https:/www.theguardian.com/film/2018/sep/03/ real-life-terror-is-it-exploitative-to-use-human-suffering-for-cinematic-thrills> (linkki tarkistettu 14.8.2020)

YLE Uutiset (2015) Turvapaikanhakijoiden bussia heitettiin ilotulitteilla, SPR:n työntekijää kivillä. Me.fi. Saatavilla: <https://yle.fi/uutiset/3-8331041> (linkki tarkistettu 28.1.2020).

Žižek, Slavoj (1997) Multiculturalism, or, the Cultural Logic of Multinational Capitalism. New Left Review vol. 1:225, 28-51.

Žižek, Slavoj (2007) Tolerance as an Ideological Category: The Culturalization of Politics. Critical Inquiry. Saatavilla: <http://www.lacan.com/zizek-inquiry.html> (linkki tarkistettu 13.8.2020).

Žižek, Slavoj (2016) The Cologne Attacks Were an Obscene Version of Carnival. New Statesman. Saatavilla: <https://www.newstatesman.com/world/europe/2016/01/slavoj-zizek-cologneattacks> (linkki tarkistettu 17.7.2020). 